LANGUAGE : Jurnal Inovasi Pendidikan Bahasa dan Sastra

Vol 1. No 2. November 2021, e-ISSN : 2807-1670 | p-ISSN : 2807-2316

\title{
PEMANFAATAN MEDIA GAMBAR BERSERI UNTUK MENINGKATKAN KETERAMPILAN MENULIS TEKS CERPEN MELALUI MODEL PEMBELAJARAN KREATIF PRODUKTIF
}

\author{
SRI INDRIYATI \\ MTs Negeri 2 Banyumas \\ e-mail: indriafasda@gmail.com
}

\begin{abstract}
ABSTRAK
Penelitian ini bertujuan untuk mendeskripsikan hasil kemampuan menulis teks cerpen dengan memanfaatkan media gambar berseri melalui model pembelajaran kreatif produk pada peserta didik kelas IX MTs Negeri 2 Banyumas. Dari hasil kondisi awal pembelajaran menulis teks cerpen sebelum menggunakan media ditemukan bahwa kemampuan rata-rata peserta didik dalam menulis cerpen masih jauh dari Kriteria Ketuntasan Minimum (KKM) yang ditetapkan, yaitu nilai $72 \mathrm{ke}$ atas. Masih banyak peserta didik yang belum mendapat nilai 72 yaitu 41,20\% sedangkan yang mendapat nilai 72 ke atas sebanyak 58,22\%. Ketidakmampuan peserta didik dalam mencapai KKM ini membutuhkan sebuah inovasi, yaitu penggunaan media gambar berseri melalui metode pembelajaran kreatif produktif dalam pembelajaran menulis teks cerpen. Sehingga ada peningkatan nilai dari hasil menulis teks cerpen yang dibuat peserta didik dengan menggunakan media gambar berseri yaitu; rata-rata kemampuan menulis teks cerpen peserta didik sudah meningkat dari sebelumnya apabila dilihat dari prosentase hasil belajar sebelumnya, setelah menggunakan media gambar berseri melalui metode pembelajaran kreatif produktif hasil pembelajaran menulis teks cerpen meningkat menjadi 82,35\%. Dari hasil tersebut dapat diketahui masih ada $17,65 \%$ peserta didik yang masih mendapatkan nilai di bawah 72, sedangkan lainnya mendapat nilai 72 ke atas. Hal ini membuktikan bahwa penggunaan media gambar berseri melalui metode pembelajaran kreatif produk dapat meningkatkan kemampuan peserta didik dalam menulis teks cerpen.
\end{abstract}

Kata Kunci: gambar berseri, teks cerpen, metode pembelajaran kreatif produktif

\section{ABSTRACT}

This study aims to describe the results of the ability to write short stories by utilizing serial image media through product creative learning models for class IX students at MTs Negeri 2 Banyumas. From the results of the initial conditions of learning to write short stories before using the media, it was found that the average ability of students in writing short stories was still far from the specified Minimum Completeness Criteria (KKM), which was a score of 72 and above. There are still many students who have not scored 72 , which is $41.20 \%$, while those who scored 72 and above are $58.22 \%$. The inability of students to achieve this KKM requires an innovation, namely the use of serial image media through productive creative learning methods in learning to write short stories. So that there is an increase in the value of the results of writing short stories made by students using serial images, namely; the average ability to write short stories of students has increased from before when viewed from the percentage of previous learning outcomes, after using serial image media through productive creative learning methods, the results of learning to write short stories increased to $82.35 \%$. From these results, it can be seen that there are still $17.65 \%$ of students who still get a score below 72, while others get a score of 72 and above. This proves that the use of serial image media through product creative learning methods can improve students' abilities in writing short stories.

Keywords: picture series, short story text, productive creative learning method

\section{PENDAHULUAN}

Menulis adalah salah satu kegiatan yang harus dihadapi peserta didik dalam proses pembelajaran, terutama untuk mata pelajaran bahasa Indonesia. Melalui kegiatan menulis diharapkan peserta didik dapat menuangkan ide-ide atau gagasan baik yang bersifat ilmiah 
maupun imajinatif. Menurut Tarigan (2008: 22), menulis merupakan kegiatan menurunkan atau melukiskan lambang-lambang grafik yang menggambarkan suatu bahasa yang dipahami oleh seseorang, sehingga orang lain dapat membaca lambang-lambang grafik itu. Kegiatan menulis juga disebut sebagai suatu kemampuan seseorang untuk mengungkapkan ide, pikiran, pengetahuan, dan pengalaman-pengalaman kehidupannya dalam bahasa tulis yang jelas, ekspresif, mudah dibaca, dan dipahami oleh orang lain.

Pembelajaran teks cerpen sebagai bagian pembelajaran sastra di madrasah seharusnya ditekankan pada kenyataan bahwa sastra merupakan salah satu bentuk seni yang diapresiasi. Sehingga, pembelajaran menulis teks cerpen harus lebih mendapat perhatian dari guru. Kegiatan pembelajaran yang baik tidak hanya mempersiapkan para peserta didik untuk bisa tuntas mencapai kompetensi yang telah ditentukan saja tetapi juga untuk menyelesaikan masalah-masalah yang dihadapi peserta didik dalam kehidupan sehari-hari.

Menurut Hidayati (2009: 91), cerpen adalah suatu bentuk karangan dalam bentuk prosa fiksi dengan ukuran yang relatif pendek, yang bisa selesai dibaca dalam sekali duduk, artinya tidak memerlukan waktu banyak. Pendapat lain dari Sayuti (2000: 10) menyatakan bahwa cerpen menunjukkan kualitas yang bersifat compression 'pemadatan', concentration 'pemusatan', dan intensity 'pendalaman', yang semuanya berkaitan dengan panjang cerita dan kualitas struktural yang diisyaratkan oleh panjang cerita itu.

Adanya pembelajaran menulis teks cerpen, diharapkan peserta didik mampu menulis kembali pikiran, perasaan, dan pengalaman dalam bentuk cerita atau narasi dengan menggunakan bahasa yang benar. Keterampilan menulis teks cerpen wajib dikuasai oleh peserta didik agar peserta didik dapat mengekspresikan pikiran, perasaan, dan pengalamannya melalui kegiatan menulis teks cerpen secara kreatif. Proses pengimajinasian atau pengembangan pengalaman lahir dan batin merupakan awal dari proses kreatif. Proses kreatif tersebut kemudian dilanjutkan dengan mengekspresikan imajinasi ke dalam rangkaian kalimat. Kalimat tersusun dengan logika dan alur yang jelas sehingga membentuk sebuah cerita atau narasi (Musarofah, 2014:2). Hal ini sejalan dengan pendapat Sukirno (2009:2) pembelajaran menulis kreatif adalah prosedur atau tahapantahapan kegiatan belajar-mengajar yang dilakukan oleh peserta didik dan guru dengan penekanan pada penciptaan kondisi belajar menulis untuk mencapai kompetensi dasar menulis yang ditentukan dengan pembelajaran berpusat pada peserta didik dan pemanfaatan media belajar. Berdasarkan pendapat-pendapat tersebut dapat disimpulkan bahwa cerpen adalah cerita yang isinya mengisahkan peristiwa pelaku cerita secara singkat yang berupa kisah atau cerita tentang manusia dan seluk beluknya lewat tulisan pendek dapat berupa peristiwa yang mengharukan atau menyenangkan, dan mengandung kesan yang tidak mudah dilupakan.

Model pembelajaran kreatif produktif dikembangkan dengan berbagai pendekatan pembelajaran yang diasumsikan dapat meningkatkan hasil belajar peserta didik. Pendekatan pembelajaran tersebut antara lain peserta didik aktif, kreatif, produktif, konstruktif, kolaboratif, dan kooperatif (Tim PKP, 2011). Pembelajaran kreatif produktif ini berlandaskan pada beberapa karakteristik yang membedakannya dengan model pembelajaran lainnya. Tim PKP (2011, pp.60-61), memberikan karakteristik penting dari setiap pendekatan pembelajaran kreatif produktif sebagai berikut: (1) Keterlibatan peserta didik secara intelektual dan emosional dalam pembelajaran. Keterlibatan ini difasilitasi melalui pemberian kesempatan kepada peserta didik untuk melakukan eksplorasi dari konsep bidang ilmu yang se-dang dikaji serta menafsirkan hasil eksplorasi tersebut. Peserta didik diberi kebebasan untuk menjelajahi berbagai sumber yang relevan dengan topik atau konsep yang sedang dikaji. Eksplorasi ini akan meningkatkan peserta didik melakukan interaksi dengan lingkungan dan pengalamannya sendiri, sebagai media untuk mengonstruksikan pengetahuannya. (2) Peserta didik didorong untuk menemukan atau mengonstruksi sendiri konsep yang sedang dikaji melalui penafsiran yang dilakukan dengan berbagai cara, seperti observasi, diskusi, atau percobaan. Dengan cara ini, konsep tidak ditransfer oleh guru kepada peserta didik, tetapi dibentuk sendiri oleh peserta didik berdasarkan pengalaman dan interaksi dengan lingkungan yang terjadi ketika melakukan eksplorasi serta interpretasi. Dengan kata lain, peserta didik didorong untuk memberikan makna 
dari pengalamannya, sehingga pemahamannya terhadap fenomena yang sedang dikaji menjadi meningkat. Disamping itu, peserta didik didorong untuk memunculkan berbagai sudut pandang terhadap topik atau konsep yang sama, dan untuk memertahankan sudut pandangnya dengan menggunakan argumentasi yang relevan. Hal-hal ini merupakan salah satu realisasi hakikat konstruktiviance dalam pembelajaran; (3) Peserta didik diberi kesempatan untuk bertanggung jawab menyelesaikan tugas bersama. Kesempatan ini diberikan melalui kegiatan eksplorasi, interpretasi, dan rekreasi. Di samping itu, peserta didik juga mendapat kesempatan untuk membantu temannya dalam menyelesaikan satu tugas. Kebersamaan, baik dalam eksplorasi, interpretasi, serta rekreasi dan pemajangan hasil karya merupakan arena interaksi yang memerkaya pengalaman; (4) Pada dasarnya, untuk menjadi kreatif, seseorang harus bekerja keras, berdedikasi tinggi, antusias, serta percaya diri (Segal dalam Black, 2014). Dalam konteks pembelajaran, kreativitas dapat ditumbuhkan dengan menciptakan suasana kelas yang memungkinkan peserta didik dan guru merasa bebas mengaji dan mengeksplorasi topik-topik penting kurikulum. Guru mengajukan pertanyaan yang membuat peserta didik berpikir keras, kemudian mengejar pendapat peserta didik tentang ide-ide besar dari berbagai perspektif. Guru juga mendorong peserta didik untuk menunjukkan atau mendemonstrasikan pemahamannya tentang topik-topik penting dalam kurikulum menurut caranya sendiri (Black, 2014). Mengacu pada karakteristik tersebut, model pembelajaran kreatif dan produktif diasumsikan mampu memotivasi peserta didik dalam melaksanakan berbagai kegiatan sehingga mereka merasa tertantang untuk menyelesaikan tugas-tugasnya secara kreatif dan pada akhirnya akan meningkatkan hasil belajar peserta didik tersebut. Karakteristik itu pula yang dapat membuat model pembelajaran ini dapat diterapkan dalam pembelajaran bahasa Indonesia untuk topiktopik yang bersifat konkret seperti pembelajaran menulis teks cerita pendek.

Berdasarkan pengalaman dan hasil pembelajaran sebelumnya, pembelajaran menulis teks cerpen kurang mencapai hasil yang diharapkan, baik dari aspek hasil pembelajarannya maupun dari aspek proses. Kurang tepatnya guru dalam menggunakan strategi dan media pembelajaran dalam mengajarkan keterampilan menulis teks cerpen menyebabkan peserta didik kurang senang dan aktif dalam kegiatan pembelajaran. Hal ini tercermin dari suasana kelas pada saat proses kegiatan pembelajaran berlangsung. Kekurangan atau kelemahan metode ceramah adalah pembelajaran hanya terpusat pada guru saja. Dengan hanya menggunakan metode ceramah di dalam pembelajaran menulis teks cerpen, kemampuan peserta didik untuk mengembangkan imajinasi terbatas. Peserta didik hanya dapat menulis teks cerpen sesuai perintah guru.

Dalam penyampaian materi guru hanya menggunakan model ceramah dan penugasan. Sehingga, perlu adanya rangsangan untuk menumbuhkan imajinasi dalam menulis teks cerpen pada peserta didik. Salah satunya adalah dengan memanfaatkan media gambar berseri melalui metode pembelajaran kreatif produktif. Model Pembelajaran Kreatif Produktif (MPKP) adalah model pembelajaran yang proses pembelajarannya berpusat pada peserta didik (student centre). Pembelajaran ini berpijak kepada teori konstruktivistik dalam hal ini belajar adalah usaha pemberian makna oleh peserta didik kepada pengalamannya. Dengan demikian, dalam pembelajaran menulis teks cerpen ini para pesera didik diharapkan dapat secara aktif mengkonstruksi sendiri pokok bahasan atau materi yang mereka dapatkan. Model pembelajaran ini terbagi menjadi 5 tahapan belajar yaitu; orientasi; eksplorasi; interpretasi; re-kreasi dan evaluasi. Tiap tahapan-tahapan ini akan secara optimal melibatkan peserta didik dalam belajar, terbentuknya keterampilan berpikir, bekerja sama, disiplin serta bertanggung jawab. Dengan demikian, model pembelajaran kreatif produktif dirasa cukup baik dalam menciptakan pembelajaran yang efektif. Penerapan model pembelajaran kreatif produktif diharapkan dapat membantu peserta didik dalam memahami suatu pokok bahasan, mengembangkan kreativitas dan juga dapat memaksimalkan hasil belajar peserta didik dalam proses belajar mengajar. (Nurhadiyansyah, 2013:2) Dari media gambar berseri, peserta didik dapat mengembangkan cerita sesuai dengan isi gambar yang ada. Berdasarkan kenyataan hasil pengamatan dan observasi di kelas IX MTs Negeri 2 Banyumas, pembelajaran menulis teks cerpen kurang mencapai hasil maksimal, baik dari segi minat maupun hasil proses pembelajaran yang 
diterapkan. Salah satu faktor utama rendahnya keterampilan menulis teks cerpen adalah metode yang digunakan dalam pembelajaran yang cenderung menggunakan metode ceramah. Padahal metode ceramah menuntut konsentrasi yang terus menerus, membatasi partisipasi peserta didik, sehingga peserta didik akan merasa jenuh dan bosan. Berdasarkan latar belakang masalah di atas, maka penulis mempunyai motivasi melaksanakan metode pembelajaran kreatif produktif pada saat mengajarkan materi pembelajaran teks cerpen dengan judul "Pemanfaatan Media Gambar Berseri untuk Meningkatkan Kemampuan Menulis Teks Cerpen Melalui Metode Pembelajaran Kreatif Produktif" Permasalahan yang terjadi dalam proses pembelajaran menulis teks cerpen di MTs Negeri 2 Banyumas adalah sebagian peserta didik kesulitan saat mereka harus mulai menulis cerita, kesulitan dalam mengimajinasi, sehingga kata-kata sulit dimunculkan. Selain itu, adanya anggapan bahwa pembelajaran menulis cerita pendek adalah hal yang tidak menarik. Dari permasalahan tersebut dapat disimpulkan bahwa faktor motivasi dalam diri peserta didik juga menentukan keberhasilan dalam menuangkan ide atau gagasannya dalam bentuk cerita pendek tanpa adanya keraguan atau rasa takut salah dalam menuangkan gagasan. Melalui penerapan metode pembelajaran kreatif produktif dalam pembelajaran menulis teks cerpen di MTs Negeri 2 Banyumas diharapkan dapat menumbuhkan dan meningkatkan krativitas peserta didik melalui kegiatan mengeksplorasi, inkuiri, penalaran, dan komunikasi.

\section{METODE PENELITIAN}

Pembelajaran menulis teks cerita pendek pada kelas IX MTs Negeri 2 Banyumas dikemas dengan cukup menarik, yaitu peserta didik dituntut untuk lebih aktif, sedangkan guru hanya sebagai fasilitator dan motivator saja sehingga kegiatan pembelajaran semakin menyenangkan ketika peserta didik diberi kesempatan untuk berekspresi dan menuangkan gagasannya dalam sebuah teks cerpen dengan media pembelajaran yaitu gambar berseri melalui metode pembelajaran kreatif produktif. Analisi data yang digunakan dalam penelitian ini adalah analisis kuantitatif yang berupa angka prestasi belajar peserta didik dan data kualitatif yang berupa persentase hasil observasi yang juga dideskripsikan dengan kata-kata. Jenis tindakan yang digunakan adalah penerapan model pembelajaran kreatif dan produktif dalam pembelajaran menulis teks cerpen berdasarkan pengalaman mengajar atau best practice guru pada saat melaksanakan pembelajaran menulis teks cerpen. Metode yang digunakan dalam penelitian ini adalah metode kuantitatif. Menurut (Sudjana dan Ibrahim, 2001: 6-7) karakteristik penelitian kuantitatif adalah sebagai berikut: :

- Menggunakan pola berpikir deduktif (rasional - empiris atau top-down), yang berusaha memahami suatu fenomena dengan cara menggunakan konsep-konsep yang umum untuk menjelaskan fenomena-fenomena yang bersifat khusus.

- Logika yang dipakai adalah logika positivistik dan menghindari hal-hal yang bersifat subjektif.

- Proses penelitian mengikuti prosedur yang telah direncanakan.

- Tujuan dari penelitian kuantitatif adalah untuk menyusun ilmu nomotetik yaitu ilmu yang berupaya membuat hokum-hukum dari generalisasinya.

- Subjek yang diteliti, data yang dikumpulkan, dan sumber data yang dibutuhkan, serta alat pengumpul data yang dipakai sesuai dengan apa yang telah direncanakan sebelumnya.

- Pengumpulan data dilakukan melalui pengukuran menggunakan alat yang objektif dan baku.

- Melibatkan penghitungan angka atau kuantifikasi data.

- Peneliti menempatkan diri secara terpisah dengan objek penelitian, dalam arti dirinya tidak terlibat secara emosional dengan subjek penelitian.

- Analisis data dilakukan setelah semua data terkumpul.

- Dalam analisis data, peneliti dituntut memahami teknik-teknik statistik.

- Hasil penelitian berupa generalisasi dan prediksi, lepas dari konteks waktu dan situasi.

- Penelitian jenis kuantitatif disebut juga penelitian ilmiah. 


\section{HASIL DAN PEMBAHASAN}

\section{Hasil}

1) Menyusun dan mempersiapkan lembar pengamatan atau observasi peserta didik.

Lembar aktivitas peserta didik digunakan untuk mengukur aktivitas peserta didik selama proses pembelajaran berlangsung.

Tabel 1. Hasil observasi aktivitas peserta didik saat pembelajaran

\begin{tabular}{|c|l|c|}
\hline No & \multicolumn{1}{|c|}{ Aktivitas Peserta didik } & Nilai \\
\hline 1 & Memperhatikan materi pembelajaran dari guru & 3 \\
\hline 2 & $\begin{array}{l}\text { Melakukan eksplorasi dengan mengamati } \\
\text { gambar berseri }\end{array}$ & 3 \\
\hline 3 & Melakukan tanya jawab tentang gambar berseri & 3 \\
\hline 4 & Menganalisis gambar berseri yang diamati & 3 \\
\hline 5 & $\begin{array}{l}\text { Menyimpulkan hasil analisis tentang gambar } \\
\text { berseri }\end{array}$ & 3 \\
\hline 6 & $\begin{array}{l}\text { Melakukan tahap re-kreasi yaitu membuat } \\
\text { produk berupa cerpen }\end{array}$ & 3 \\
\hline 7 & Merangkum kegiatan pembelajaran & 3 \\
\hline & Jumlah & $\mathbf{2 1}$ \\
\hline & Persentase & $\mathbf{7 5 \%}$ (Baik) \\
\hline
\end{tabular}

Ket : Nilai maksimal 4

2) Menyiapkan media pembelajaran, yaitu gambar berseri

Untuk mempermudah peserta didik dalam mengikuti proses pembelajaran dan meningkatkan keaktifan peserta didik selama proses pembelajaran, guru mempersiapkan media pembelajaran gambar berseri. Media gambar berseri berisi tentang gambar bencana banjir yang sesuai dengan materi yang dipelajari, yaitu menulis teks cerpen.

3) Membuat soal tes

Soal tes dikerjakan peserta didik pada setiap akhir pertemuan, yaitu untuk mengetahui keberhasilan peserta didik dalam menguasai materi pembelajaran yang dilaksanakan. Peserta didik diajak untuk menulis teks cerpen berdasarkan gambar berseri yang diberikan oleh guru.

Dari hasil kegiatan pada pembelajaran menulis teks cerpen dengan menggunakan media gambar berseri diperoleh bahwa prestasi belajar peserta didik mengalami peningkatan pengaruh yang besar terhadap peserta didik dalam proses kreatifnya saat menciptakan sebuah teks cerpen. Sedangkan rekapitulasi hasil nilai menulis teks cerpen yang diciptakan peserta didik dapat dilihat pada tabel berikut.

Tabel 2. Rekapitulasi hasil belajar peserta didik

\begin{tabular}{|l|c|c|}
\hline \multicolumn{1}{|c|}{ Prestasi Belajar } & $\begin{array}{c}\text { Sebelum menggunakan } \\
\text { media gambar berseri }\end{array}$ & $\begin{array}{c}\text { Sesudah menggunakan } \\
\text { media gambar berseri }\end{array}$ \\
\hline Ketuntasan Belajar & $58,80 \%$ & $82,35 \%$ \\
\hline Ketidaktuntasan Belajar & $41,20 \%$ & $17,65 \%$ \\
\hline
\end{tabular}




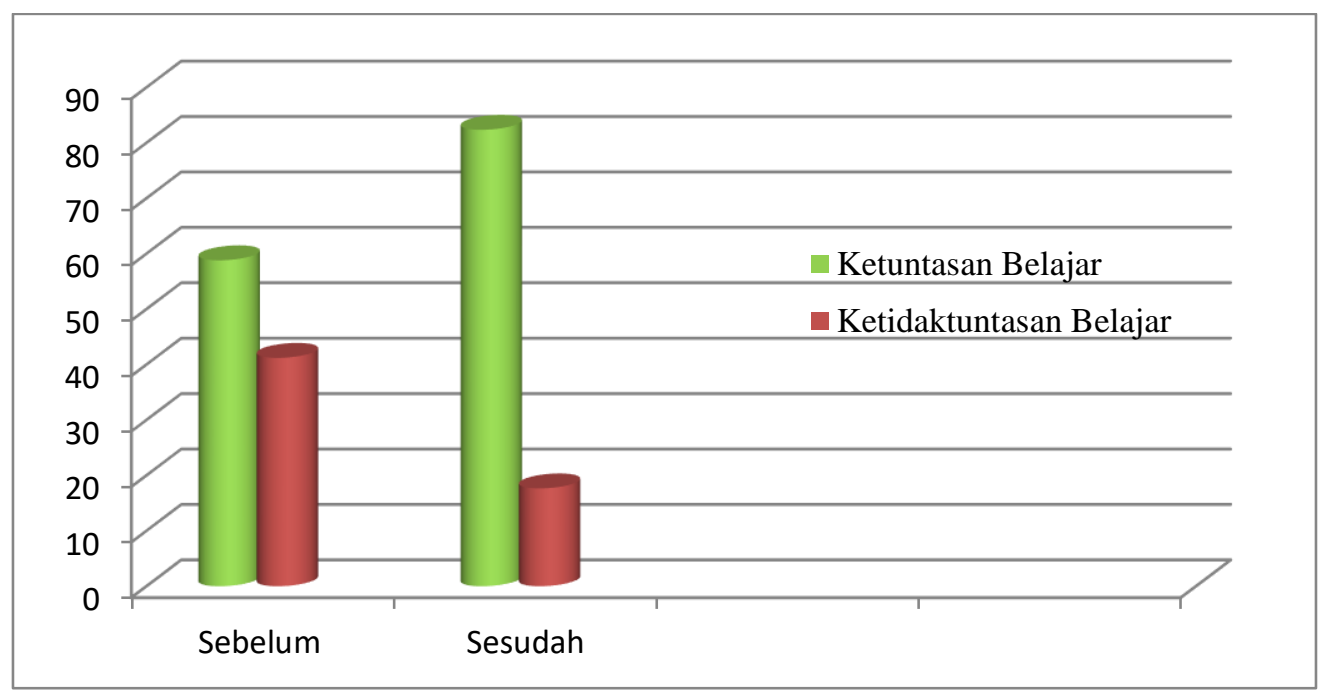

Gambar 1.hasil prestasi belajar peserta didik

Berdasarkan pada gambar yang menunjukkan tentang hasil belajar peserta didik tersebut dapat dilihat bahwa hasil kondisi awal pembelajaran menulis teks cerpen sebelum menggunakan media gambar berseri dan metode pembelajaran kreatif produktif ditemukan bahwa kemampuan rata-rata peserta didik dalam menulis cerpen masih jauh dari Kriteria Ketuntasan Minimum (KKM) yang ditetapkan, yaitu nilai 72 ke atas. Masih banyak peserta didik yang belum mendapat nilai 72 yaitu $41,20 \%$ sedangkan yang mendapat nilai 72 ke atas sebanyak 58,22\%. Ketidakmampuan peserta didik dalam mencapai KKM ini membutuhkan sebuah inovasi, yaitu penggunaan media gambar berseri dalam pembelajaran menulis teks cerpen. Sehingga ada peningkatan nilai dari hasil menulis teks cerpen yang dibuat peserta didik dengan menggunakan media gambar berseri yaitu; rata-rata kemampuan menulis teks cerpen peserta didik sudah meningkat dari sebelumnya apabila dilihat dari prosentase hasil belajar sebelumnya, setelah menggunakan media gambar berseri dalam pembelajaran menulis teks cerpen meningkat menjadi $82,35 \%$. Dari hasil tersebut dapat diketahui masih ada $17,65 \%$ peserta didik yang masih mendapatkan nilai di bawah 72, sedangkan lainnya mendapat nilai 72 ke atas. Hal ini membuktikan bahwa penggunaan media gambar berseri dan model pembelajaran kreatif produktif dapat meningkatkan kemampuan peserta didik dalam menulis teks cerpen.

Dari hasil kondisi awal pembelajaran menulis teks cerpen sebelum menggunakan media dan metode pembelajaran kreatif produktif ditemukan bahwa kemampuan rata-rata peserta didik dalam menulis cerpen masih jauh dari Kriteria Ketuntasan Minimum (KKM) yang ditetapkan, yaitu nilai 72 ke atas. Masih banyak peserta didik yang belum mendapat nilai 72 yaitu $41,20 \%$ sedangkan yang mendapat nilai 72 ke atas sebanyak 58,22\%. Ketidakmampuan peserta didik dalam mencapai KKM ini membutuhkan sebuah inovasi, yaitu penggunaan media gambar berseri dalam pembelajaran menulis teks cerpen dan penggunaan metode pembelajaran kreatif produktif. Sehingga ada peningkatan nilai dari hasil menulis teks cerpen yang dibuat peserta didik dengan menggunakan media gambar berseri dan metode pembelajaran kreatif produktif yaitu; rata-rata kemampuan menulis teks cerpen peserta didik sudah meningkat dari sebelumnya apabila dilihat dari prosentase hasil belajar sebelumnya, setelah menggunakan media gambar berseri dalam pembelajaran menulis teks cerpen meningkat menjadi $82,35 \%$. Dari hasil tersebut dapat diketahui masih ada $17,65 \%$ peserta didik yang masih mendapatkan nilai di bawah 72, sedangkan lainnya mendapat nilai 72 ke atas. Hal ini membuktikan bahwa penggunaan media gambar berseri dan metode pembelajaran kreatif produktif dapat meningkatkan kemampuan peserta didik dalam menulis teks cerpen.

\section{Pembahasan}


Masalah yang dihadapi terutama adalah peserta didik yang belum terbiasa menulis teks cerpen dengan panduan gambar berseri. Penggunaan media gambar berseri ini didasari atas kemampuan peserta didik dalam menulis teks cerpen yang relatif masih rendah. Keadaan ini disebabkan oleh beberapa hal, diantaranya guru merasa kesulitan untuk melaksanakan pembelajaran menulis teks cerpen. Guru masih kurang maksimal dalam memotivasi peserta didik untuk dapat menulis teks cerpen dengan baik. Selain itu, peserta didik membutuhkan daya imajinatif yang tinggi dalam menulis teks cerpen yang baik dan menarik melalui penerapan metode pembelajaran kreatif produktif.

Cara untuk mengatasi permasalahan tersebut, penulis/guru mengembangkan karya inovasi pembelajaran yang diberi nama Media Gambar Berseri dalam Pembelajaran Menulis Teks Cerpen. Media ini diharapkan dapat menginspirasi dan membangkitkan motivasi serta meningkatkan daya imajinasi peserta didik dalam membuat cerpen yang baik dan menarik. Dengan demikian, media gambar berseri merupakan salah satu media yang dapat digunakan dalam pembelajaran menulis teks cerpen. Media ini merupakan kartu yang berisi gambar berseri, gambar-gambar tersebut penulis peroleh dari internet kemudian dicetak dan diberi nomor per gambar tersebut. Media gambar berseri ini dapat digunakan peserta didik dalam pembelajaran menulis teks cerpen baik di dalam kelas maupun di luar kelas. Media gambar berseri ini dikembangkan dengan tujuan membangkitkan motivasi belajar peserta didik, meningkatkan daya imajinasi peserta didik, dan meningkatkan daya tarik pembelajaran menulis teks cerpen.

Tabel 3. Proses Kreatif Peserta Didik dalam Menulis Teks Cerpen

\begin{tabular}{|c|l|l|l|}
\hline No. & \multicolumn{1}{|c|}{ Aspek } & \multicolumn{1}{|c|}{$\begin{array}{c}\text { Sebelum menggunakan } \\
\text { media gambar berseri }\end{array}$} & $\begin{array}{c}\text { Sesudah menggunakan } \\
\text { media gambar berseri }\end{array}$ \\
\hline 1. & Penentuan judul & $\begin{array}{l}\text { Peserta didik dalam } \\
\text { menentukan judul cerpen } \\
\text { kebanyakan pada awal } \\
\text { membuat cerpen, yang dapat } \\
\text { memberi arah dalam } \\
\text { penulisan cerpen. }\end{array}$ & $\begin{array}{l}\text { Peserta didik mulai } \\
\text { berani menentukan judul } \\
\text { cerpen di tengah atau di } \\
\text { akhir proses penciptaan } \\
\text { teks cerpen yang } \\
\text { disesuaikan dengan } \\
\text { cerpen yang ditulis. }\end{array}$ \\
\hline 2. & $\begin{array}{l}\text { Penentuan tokoh, } \\
\text { alur, setting, dan } \\
\text { amanat }\end{array}$ & $\begin{array}{l}\text { Peserta didik dalam } \\
\text { menentukan alur, tokoh, } \\
\text { setting, dan amanat cerpen } \\
\text { dalam penulisan teks cerpen } \\
\text { kurang variatif. }\end{array}$ & $\begin{array}{l}\text { Penentuan tokoh, alur, } \\
\text { setting, dan amanat } \\
\text { semakin variatif. }\end{array}$ \\
\hline 3. & Suasana Belajar & $\begin{array}{l}\text { Suasana belajar terkesan } \\
\text { kaku, pasif, dan kurang } \\
\text { mendukung proses } \\
\text { pembelajaran kreatif } \\
\text { produktif dalam mencipta } \\
\text { cerpen. }\end{array}$ & $\begin{array}{l}\text { Suasana belajar lebih } \\
\text { menyenangkan, terjalin } \\
\text { kerjasama antar peserta } \\
\text { didik, dan komunikatif } \\
\text { sehingga mempermudah } \\
\text { peserta didik dalam } \\
\text { menciptakan cerpen } \\
\text { melalui pembelajaran } \\
\text { kreatif produktif. }\end{array}$ \\
\hline
\end{tabular}

Dari tabel di atas dapat dijelaskan bahwa penggunaan media gambar berseri dan metode pembelajaran kreatif produktif dalam pembelajaran menulis teks cerpen mempunyai pengaruh yang besar terhadap peserta didik dalam proses kreatifnya saat menciptakan sebuah teks cerpen. Berkaitan dengan pemanfaatan gambar berseri dalam meningkatkan keterampilan menulis teks cerpen melalui metode pembelajaran kreatif produktif memperkuat fungsi penggunaan media dalam pembelajaran yang dapat memberikan banyak manfaat sepanjang guru dapat berperan 
aktif dalam proses pembelajaran. Sebagaiamana yang disampaikan Sarudi (2018) bahwa hubungan guru dan peserta didik merupakan elemen penting dalam sistem pendidikan. Guru harus selalu hadir untuk menyajikan suatu materi pelajaran dengan menggunakan media yang tepat dan menarik agar tujuan pembelajaran dapat tercapai dengan hasil yang baik. Hal ini juga memperkuat pendapat Arsyad (2004) bahwa manfaat media pembelajaran adalah (1) memperjelas penyajian pesan dan informasi, (2) meningkatkan dan mengarahkan perhatian peserta didik sehingga dapat menimbulkan motivasi belajar dan interaksi secara langsung, dan (4) memberikan kesamaan pengalaman kepada peserta didik. Dengan demikian pemanfaatan media dalam pembelajaran sangat berpengaruh terhadap motivasi dan semangat belajar peserta didik. Media pembelajaran dapat membawa dan membangkitkan rasa senang serta motivasi bagi peserta didik serta dapat mempengaruhi semangat mereka, sehingga dapat membantu pemahaman pengetahuan peserta didik dalam pembelajaran bahasa Indonesia. Hasil peneltian ini juga relevan dengan penelitian yang dilakukan oleh Musarofah (2014), tentang Pemanfaatan Media Gambar Berseri dalam Meningkatkan Keterampilan Menulis Teks Cerpen Pada Peserta Didik Kelas X SMA Muhammadiyah Purwokerto Tahun Pelajaran 2013/2014. Relevansi penelitian Musarofah dengan penelitian ini adalah terletak pada análisis peningkatan keterampilan menulis teks cerpen, sedangkan perbedaannya terletak pada pendekatannya. Terkait dengan metode pembelajaran kreatif produktif yang diguanakan dalam pembelajaran menulis teks cerpen dalam penelitian ini juga relevan dengan Oya (2014). Relevansi penelitian Oya dengan penelitian ini adalah terletak pada metode peningkatan hasil belajar yang digunakan, sedangkan perbedaannya pada perbandingan metodenya.

\section{KESIMPULAN}

Berdasarkan uraian dan pemaparan di atas dapat disimpulkan hal-hal sebagai berikut.

1. Jika peserta didik senang dan serius menerima pelajaran yang disampaikan oleh seorang guru, maka potensi untuk menyerap materi pembelajaran tersebut lebih besar. Dalam mengajar diperlukan metode dan media pembelajaran yang inovatif, menarik, serta menyenangkan agar tujuan pembelajaran dapat tercapai. Salah satunya dengan menggunakan media gambar berseri melalui metode pembelajaran kreatif produktif dalam pembelajaran menulis teks cerpen.

2. Media gambar berseri ini dibuat dengan cara mencari gambar-gambar berseri dari internet kemudian mencetaknya dan tiap gambar diberi nomor, gambar-gambar berseri tersebut sebagai sumber imajinasi peserta didik dalam mengembangkan penulisan sebuah teks cerpen.

3. Pembuatan media gambar berseri dalam pembelajaran menulis teks cerpen relatif mudah. Setelah mempersiapkan alat dan bahan dibuatlah media ini sehingga dapat memotivasi dan meningkatkan daya imajinasi peserta didik dalam membuat cerpen yang baik. Alasan pembuatan media gambar berseri ini karena media ini mudah dibuat dan murah serta praktis dan mudah. Pembuatan media gambar berseri ini membuat guru akan lebih mudah dalam memberikan materi pelajaran terutama dalam pembelajaran menulis teks cerpen. Kendala yang dihadapi dalam pembuatan media gambar berseri ini adalah masih terbatasnya sumber gambar berseri yang terbatas. Penggunaan media gambar berseri ini dapat meningkatkan proses kreatif peserta didik dalam menulis teks cerpen dan juga hasil cerpen yang lebih baik dibandingkan dengan tanpa penggunaan media gambar berseri. Media gambar berseri dapat memotivasi dan meningkatkan daya imajinasi peserta didik dalam menulis teks cerpen yang baik. Dengan media gambar berseri dan metode pembelajaran kreatif produktif, peserta didik terbantu dalam menulis teks cerpen dengan baik dan menarik. Cerita, alur, karakter tokoh, dan amanat lebih variatif dan peserta didik lebih mudah dalam menentukan isi teks cerpen yang akan ditulis.

\section{DAFTAR PUSTAKA}

Arsyad, Azhar. (2014). Media Pembelajaran. Jakarta: PT. Raja Grafindo Persada. 
Depdiknas. (2005). Kamus Besar Bahasa Indonesia. Jakarta: Depdiknas.

Hidayati, Panca Pertiwi. (2009). Teori Apresiasi Prosa Fiksi. Bandung: Prisma Press Prodaktama.

Musarofah, Ika. (2014). Pemanfaatan Media Gambar Berseri dalam Meningkatkan Keterampilan Menulis Cerpen pada Peserta didik kelas X SMA Muhammadiyah Purwokerto Tahun Pelajaran 2013/2014. Skripsi: Purwokerto: UMP.

Nurhadiyansyah. (2013). Pengaruh Penggunaan Model Pembelajaran Kreaif Poduktif Terhadap hasil belajar peserta didik (Studi eksperimen dikelas V Madrasah Ibtidaiyah Negeri Padamatang). Skripsi. Cirebon:2013.

Oya, Rini Ntowe. (2014). Peningkatan Motivasi Hasil Belajar Bahasa Indonesia Menggunakan Model Pembelajaran Kreatif Produktif. Yogyakarta: Jurnal Prima Edukasia, Volume 2 - Nomor 1.

Sarudi, Wawan. (2018). Penggunaan Media Kartu Gambar Berseri Untuk Meningkatkan Kemampuan Menulis Teks Cerpen. Malang : Jurnal Hasta Wiyata.

Sayuti, Suminto. (2000). Kajian Fiksi. Yogyakarta : Gama Media.

Sudjana dan Ibrahim. (2001). Penelitian dan Penilaian Pendidikan. Bandung: Sinar Baru Algensindo.

Sukirno. (2009). Pembelajaran Menulis Kreatif dengan Strategi Belajar Akselerasi. Purworejo: UM Purworejo Press.

Tarigan, Henry Guntur. (2008). Menulis sebagai Suatu Keterampilan Berbahasa. Bandung: Angkasa.

Tim PKP. (2011). Peningkatan kualitas pembelajaran. Jakarta: Depdiknas 